\title{
Expression and Functional Significance of Alternatively Spliced CS1 Fibronectin in Rheumatoid Arthritis Microvasculature
}

\author{
Mariano J. Elices, Van Tsai, * Dana Strahl, Amita S. Goel, Vanessa Tollefson, Thomas Arrhenius, \\ Elizabeth A. Wayner, Federico C. A. Gaeta, John D. Fikes, and Gary S. Firestein * \\ Cytel Corporation, San Diego, California 92121; and *Division of Rheumatology, \\ University of California, San Diego Medical Center, San Diego, California 92103
}

\begin{abstract}
Expression of fibronectin (FN) isoforms containing CS1, a 25amino acid sequence present within the alternatively spliced IIICS region of $\mathrm{FN}$, has been analyzed in rheumatoid arthritis (RA) synovium. Unexpectedly, CS1-containing FN variants were exclusively found on endothelium but not extracellular matrix ( ECM) of RA synovium. Lumenal expression of CS1 on RA endothelial cells, as observed by electron microscopy, correlated with inflammation in RA, since normal synovium expressed little CS1 without appreciable decrease in ECM FN. CS1 expression on human endothelial cells was further shown by $F N$ mRNA analyses. In adhesion assays on frozen $R A$ synovial sections, $T$ lymphoblastoid cells expressing functionally activated $\alpha 4 \beta 1$ integrin specifically attached to the intravascular surface of RA endothelium. Binding was abrogated by both anti- $\alpha 4$ integrin and CS1 peptides. Our observations suggest direct involvement of CS1-containing FN in recruitment of $\alpha 4 \beta 1$-expressing mononuclear leukocytes in synovitis, and provide basis for therapeutic intervention in RA. (J. Clin. Invest. 1994. 93:405-416.) Key words: cell adhesion • integrins • CS1 fibronectin • inflammation • VLA-4
\end{abstract}

\section{Introduction}

Fibronectin $(\mathrm{FN})^{1}$ is a ubiquitous extracellular matrix (ECM) protein that provides the architectural scaffolding in tissues and can also be found in body fluids such as plasma (for a review, see reference 1 ). Although $\mathrm{FN}$ is encoded by a single gene, FN polypeptide diversity is generated by alternative splicing of a primary FN RNA transcript (2-4). Patterns of FN gene splicing are regulated in a cell type-specific fashion, and presumably play a central role in such dynamic processes as embryogenesis $(5,6)$, wound healing $(7)$, viral transformation $(8)$, and aging (9).

Address correspondence to Dr. Mariano J. Elices, Cytel Corporation, 3525 John Hopkins Court, San Diego, CA 92121 . E. A. Wayner's present address is the University of Minnesota, Minneapolis, MN 55455.

Received for publication 12 May 1993 and in revised form 7 September 1993.

1. Abbreviations used in this paper: D-PBS, Dulbecco's PBS; EC, endothelial cell; ECM, extracellular matrix; EM, electron microscopy; FN, fibronectin; HUVEC, human umbilical vein endothelial cell; OVA, ovalbumin; RA, rheumatoid arthritis; VCAM, vascular cell adhesion molecule.

J. Clin. Invest.

(c) The American Society for Clinical Investigation, Inc. $0021-9738 / 94 / 01 / 0405 / 12 \$ 2.00$

Volume 93, January 1994, 405-416
The FN gene contains three separate exons that are subject to alternative splicing, termed EIIIA, EIIIB, and V or IIICS (1). The presence of additional acceptor and donor splice signals within the IIICS region allows generation of increased diversity in FN by virtue of multiple IIICS polypeptide variants, namely, three in rat $\mathrm{FN}(2,10)$ and five in human $\mathrm{FN}(11,12)$. One subset of these molecular variants expresses a 25 -amino acid sequence termed CS1 $(13,14)$, which is a counter-receptor for the $\alpha 4 \beta 1$ (also known as VLA-4) integrin $(15,16)$. To date, the VLA-4/CS1 interaction has been widely documented in hematopoiesis where adhesive interactions between hematopoietic progenitors expressing VLA-4 (17-20) and their ECM microenvironment play a critical role in precursor maturation and differentiation. Thus, CS1 peptides have been shown to inhibit: $(a)$ attachment of murine hematopoietic stem cells to ECM derived from bone marrow stroma $(18),(b)$ immunoglobulin secretion by bone marrow-derived B cell progenitors (19), and $(c)$ thymocyte adhesion and differentiation induced by thymic stromal cell monolayers $(20,21)$. VLA-4/CS1 may also be involved in embyonic development, since CS1 peptides have been shown to interfere with migration of avian neural crest cells (22).

VLA-4, which is predominantly expressed on lymphocytes, monocytes, and eosinophils, but not on neutrophils (17), also serves as a receptor for the cytokine-inducible vascular cell adhesion molecule type 1 (VCAM-1) $(23,24)$. The dual interaction of VLA-4 on leukocytes with either endothelial VCAM-1, or CS1-containing FN in the ECM, has been postulated to play a key role in leukocyte trafficking during inflammation $(23,25$, 26). In a murine model of contact hypersensitivity, CS1 peptide partially inhibited recruitment of $\mathrm{T}$ lymphocytes to skin inflammatory sites (27). Since the Arg-Gly-Asp peptide from the cell adhesion domain of FN was also inhibitory in this animal model, the authors concluded that emigration of immune $T$ cells to sites of antigenic challenge in the tissue could be facilitated by the interaction of leukocyte integrins with ECM proteins such as FN (27). In conclusion, none of the studies reported to date offer a precedent for endothelial expression of CS1-containing FN.

Rheumatoid arthritis (RA) is a chronic inflammatory condition whereby a large number of mononuclear cells, mostly CD4 memory T cells (28-30) and macrophages, accumulate in perivascular areas within the synovial membrane (for reviews, see references 31 and 32). Although significant accumulation of lymphocytes, monocytes, and neutrophils in the synovial fluid occurs, very few neutrophils actually infiltrate the synovial membrane itself $(31,32)$. RA pathology is also characterized by hyperplasia of the synovial intimal lining, which is normally a single layer of fibroblast-like and macrophage-like cells at the interface with the joint space. Development of an extensive network of new blood vessels within the synovial membrane and local release of inflammatory cytokines $(33,34)$ 
facilitate adherence of circulating lymphocytes to postcapillary synovial venules. Ultimately, proliferation of the synovial membrane leads to invasion and irreversible destruction of cartilage and subchondral bone $(31,32)$.

We now report data implicating VLA-4/CS1 in the pathogenesis of RA. Immunohistochemical studies clearly indicate that CS1 is selectively expressed on RA, but not normal, synovium. In contrast to ECM forms of FN, CS1 expression is limited to RA synovial vasculature and intimal lining. CS1 on RA synovium specifically localizes to the lumenal surface of endothelial cells, and is capable of mediating intravascular attachment of $\mathrm{T}$ lymphocytes that express a functionally activated form of VLA-4. Taken together, our results suggest an important role for CS1 in the recruitment of mononuclear leukocytes in RA synovium, and provide a potential approach for therapeutic intervention in RA.

\section{Methods}

Patient selection and tissue preparation. Synovial tissue was obtained at the time of joint replacement surgery or synovectomy from patients with classic or definite RA (35). All tissues were immediately snap frozen in 2-methyl-butane and liquid nitrogen, and stored at $-70^{\circ} \mathrm{C}$ until used. One normal synovium was obtained from a patient who had a total hip replacement to repair a nonhealing fracture, and four additional normal knee synovia were obtained at the time of autopsy from individuals without arthritis who died of unrelated causes. The autopsy specimens were processed within $6 \mathrm{~h}$ of death.

$m A b s$, peptides, and cell lines. The following mAbs were used in this study: P4C2 (IgG3, anti- $\alpha 4$ ) (15), LB3.1 (IgG2a, anti-class II DR antigens), P1G12 (IgG1, anti-PECAM-1/CD31), and P3H12 (IgG1, anti-VCAM-1) (36) (all from Cytel Corp., San Diego, CA). MOPC 104E (IgM, mouse myeloma protein) was obtained from Organon Teknika Corp. (West Chester, PA); mAb to collagen type IV (IgG) was a gift from S. Sobin (University of Southern California, Los Angeles, CA); 4B9 (IgG1, anti-VCAM-1, which abrogates VLA-4-dependent leukocyte adhesion to both the six- and seven-Ig domain forms of VCAM-1 in vitro) $(37,38)$ was a gift from J. Harlan (University of Washington, Seattle, WA); 8A2 (IgG1, adhesion-promoting anti- $\beta 1$ ) (39) was a gift from N. Kovach (University of Washington, Seattle, WA). In addition, 4C7 (IgG2a, specific for the A chain of human laminin ) (40), 3E3 (IgG1, to a constant epitope on the cell attachment region of $\mathrm{FN}$ ) (41), 3E1 (IgG1, to the $\mathrm{COOH}$-terminal heparin binding region of FN) (41), 4B2 (IgG1, to the collagen binding region of FN) (41), and P1D6 (IgG3, anti- $\alpha 5$ ) were obtained from Telios Pharmaceuticals (San Diego, CA). mAbs FN-15 (IgG1, to a framework epitope in FN) and DH1 (IgG1, to the alternatively spliced EIIIA domain of FN) (42) were purchased from ICN Biomedicals (Costa Mesa, CA).

The following peptides were chemically synthesized at Cytel Corp.: intact CS1 25-mer DELPQLVTLPHPNLHGPEILDVPST for mAb screening and adhesion assays; CYLHGPEILDVPST (CS1-C) for generation of anti-CS1 mAbs (see below) and mAb screening; CYDELPQLVTLPHP (CS1-N) and CYTLPHPNLHGPEI (CS1-M) for mAb screening; GPEILDVPST (CS1), VIPDLTESPG (scrambled CS1), and DELPQLVTLPHP (control peptide) for cell adhesion assays on frozen RA tissue sections.

T lymphoblastoid cell lines Jurkat and Molt-4 were obtained from the American Type Culture Collection (Rockville, MD), and the EBVtransformed human lymphoblastoid B cell line MAT-2 was kindly donated by C. Oseroff (Cytel Corp.). All cells were grown in RPMI 1640 supplemented with $10 \%$ FCS.

Generation and characterization of anti-CS1 mAbs. BALB/c mice (The Jackson Laboratory, Bar Harbor, ME) were immunized by biweekly intraperitoneal injections with the peptide CYLHGPEILDVPST (CS1-C) coupled to keyhole limpet hemocyanin via the $\mathrm{NH}_{2}$-terminal cysteine residue. Mouse spleen cells were fused with FOX-NY my- eloma cells according to standard techniques, and viable heterokaryons were grown in 96-well plates using adenine/aminopterine/thymidine in RPMI 1640 as selection media. Hybridomas were screened by a sandwich ELISA using three different substrates immobilized on plastic, namely, the entire CS1 25-amino acid sequence (i.e., DELPQLVTLPHPNLHGPEILDVPST), peptide CS1-C coupled to ovalbumin (OVA), and plasma FN (Telios Pharmaceuticals, San Diego, CA). Immunoreactive hybridoma supernatants were detected by using goat anti-mouse second antibody coupled to horseradish peroxidase (Boehringer Mannheim Biochemicals, Indianapolis, IN), followed by incubation with $0.4 \mathrm{mg} / \mathrm{ml} o$-phenylenediamine and $0.02 \% \mathrm{H}_{2} \mathrm{O}_{2}$ as substrates for the peroxidase-catalyzed reaction, and quantitation by measuring absorbance at $492 \mathrm{~nm}$ in an ELISA plate reader. Hybridomas selected by immunoreactivity with all three substrates were cloned by limiting dilution. Of a total of six anti-CS1 mAbs, two were selected for immunocytochemistry and adapted to serum-free cell culture conditions, namely 90.45 (stains unfixed tissue sections) and 321 (stains paraformaldehyde-fixed sections).

Immunoperoxidase staining. Frozen sections of synovial tissue ( 5 $\mu \mathrm{m}$ thick) were mounted on precoated slides (Fisher Scientific, Springfield, $\mathrm{NJ}$ ) and dried under vacuum for $5 \mathrm{~min}$. Sections were fixed in acetone for $5 \mathrm{~min}$ at $4^{\circ} \mathrm{C}$, vacuum dried for $5 \mathrm{~min}$, and rehydrated in PBS containing $10 \%$ horse serum for 10 min followed by $10 \%$ human $A B$ serum in PBS for 20 min. Synovial sections were incubated with an appropriate concentration of primary antibody $(1-5 \mu \mathrm{g} / \mathrm{ml})$ diluted in PBS with $10 \%$ human serum for $45 \mathrm{~min}$ at $4^{\circ} \mathrm{C}$. Controls were performed with isotype-matched mAbs at identical concentrations. After washing the slides three times with PBS, biotinylated horse anti-mouse second antibody (Vector Laboratories, Burlingame, CA) was added for $30 \mathrm{~min}$ at $4^{\circ} \mathrm{C}$. Slides were washed three times with PBS, and endogenous peroxidase was depleted with $0.3 \%$ hydrogen peroxide in PBS for $20 \mathrm{~min}$. Tissues were then incubated with $A B C$ horseradish peroxidase complex (Vector Laboratories, Burlingame, CA) for $30 \mathrm{~min}$ at $4^{\circ} \mathrm{C}$. The peroxidase-catalyzed reaction was developed with $0.5 \mathrm{mg} / \mathrm{ml}$ diaminobenzidine (DAB) and $0.02 \%$ hydrogen peroxide for 3-5 min at room temperature.

Immunoelectron microscopy. Synovial specimens obtained from surgery were dissected into $2-4-\mathrm{mm}$ pieces, and fixed for $3 \mathrm{~h}$ in freshly prepared $0.01 \mathrm{M}$ periodate, $0.075 \mathrm{M}$ lysine, $1 \%$ paraformaldehyde in PBS, pH 7.4 (43). The tissues were then rinsed stepwise in PBS supplemented with increasing concentrations of sucrose $(5,10,15$, and $20 \%$ weight / vol) for $1 \mathrm{~h}$ at each concentration, followed by a final rinse with $25 \%$ sucrose, glycerol. At this point, tissues were snap frozen in OTC, sectioned at 4- $\mu \mathrm{m}$ thickness, placed onto poly-L-lysine-coated (1 mg/ $\mathrm{ml}$ ) methylpentene plates (Nunc, Naperville, IL), and finally rehydrated with $1 \%$ BSA in PBS. The tissues were then stained using the immunoperoxidase method as described above, and processed for routine electron microscopy (EM). Briefly, sections were fixed for $1 \mathrm{~h}$ with $2 \%$ glutaraldehyde, followed by $1 \%$ osmium tetroxide for $1 \mathrm{~h}$ on ice. Next, sections were dehydrated in a stepwise graded concentration of alcohol, and embedded in Spur plastic resin. The embedded tissues were removed from the methylpentene plates, and the synovial blood vessels and synovial lining area were identified and cut out with a jewelry hacksaw. These pieces were mounted onto blocks, and ultrathin en face sectioning ( $500 \AA)$ was performed. The ultrathin sections were viewed with an electron microscope (300; Philips Technologies, Torrance, CA).

Northern blot and ribonuclease protection analyses of FN $m R N A$. Messenger RNA (4-10 × $10^{6}$ cells each) was prepared from MAT-2 (an EBV-transformed human lymphoblastoid B line) and IL- $1 \beta$ treated ( $15 \mathrm{U} / \mathrm{ml}, 4 \mathrm{~h})$ HUVEC according to the suggested manufacturer's procedure (PolyATtract system 1000; Promega Biotec, Madison, WI). Probes used for Northern and RNase protection analyses were as follows: ${ }^{32}$ P-labeled RNA probes complementary to FN cDNA (3) regions 2619-2978 (HepII, 350 nucleotides) and 3081-3154 (CS1, 74 nucleotides) were synthesized using T7 RNA polymerase (MAXIscript T7 in vitro Transcription Kit; Ambion, Austin, TX) and gel purified. Due to the inclusion of 76 nucleotides of vector-derived se- 
quence, the intact HepII and CS1 radiolabeled probes were 436 and 150 nucleotides long, respectively. For Northern blot analysis, $1 \mu \mathrm{g}$ mRNA/lane was separated on a $1 \%$ agarose/formaldehyde gel and transferred to a nitrocellulose membrane (Schleicher \& Schuell, Inc., Keene, NH). Duplicate membranes were separately hybridized with the radiolabeled HepII and CS1 riboprobes $\left(10^{6} \mathrm{cpm} / \mathrm{ml}\right.$, overnight at $\left.55^{\circ} \mathrm{C}\right)$. Stringent wash conditions $\left(22^{\circ} \mathrm{C}, 1.0 \times \mathrm{SSC}\right.$; and $65^{\circ} \mathrm{C}$, $0.1 \times$ SSC, twice, $30 \mathrm{~min}$ each) were used, followed by autoradiography. A 0.24-9.5-kb RNA ladder was used to determine approximate transcript sizes (Bethesda Research Laboratories, Gaithersburg, MD). For each ribonuclease protection assay, radiolabeled probe $(\sim 8.7$ $\left.\times 10^{4} \mathrm{cpm}\right)$ and IL- $\beta$-treated HUVEC mRNA $(0.25 \mu \mathrm{g})$ were used with ribonuclease protection assay reagents (RPA II; Ambion, Austin, TX). Various digestion conditions were tested for the assay, and Fig. 4 $B$ shows results using a 1:1,000 dilution of a stock containing RNase A (33.3 Kunitz $\mathrm{U} / \mathrm{ml})$ and RNase T1 $(10,000 \mathrm{U} / \mathrm{ml})$. Protected RNA fragments were separated on a $6 \%$ polyacrylamide $/ 8 \mathrm{M}$ urea gel using standard techniques (44), and visualized by autoradiography.

Cell adhesion assay on synovial frozen sections. The assay was modified from the original method of Stamper and Woodruff (45). Frozen synovial tissue sections ( $10-12 \mu \mathrm{m}$ thick) were placed onto Superfrost/ Plus slides (Fisher Scientific, Indianapolis, IN), air dried, and fixed with $1 \%$ paraformaldehyde, $0.1 \mathrm{M}$ sucrose in Dulbecco's PBS (D-PBS) for $15 \mathrm{~min}$ at $4^{\circ} \mathrm{C}$. Slides were rinsed once in D-PBS, and a ring was drawn around the sections with a diamond etcher in order to contain liquid samples placed on top. Sections were washed twice with D-PBS for 15 min each, and blocked with 5\% BSA in RPMI 1640 (BSA/ RPMI) for $2 \mathrm{~h}$ at room temperature. During this incubation, lymphoblastoid cell lines (i.e., Jurkat and Molt-4) were washed sequentially with $1 \mathrm{mM}$ EDTA in PBS, followed by $5 \%$ BSA/RPMI, and finally resuspended at $50 \times 10^{6}$ cells $/ \mathrm{ml}$ in $5 \% \mathrm{BSA} / \mathrm{RPMI}$. Cell suspensions were treated with inhibitors for $30 \mathrm{~min}$ at room temperature, and subsequently $100-\mu \mathrm{l}$ aliquots $\left(2.5 \times 10^{6}\right.$ cells/section $)$ were overlaid on top of synovial sections and incubated with gentle rocking for $15 \mathrm{~min}$ at room temperature. Unbound cells were decanted, and sections were washed three times in D-PBS with gentle agitation for $1 \mathrm{~min}$. Bound cells were fixed with $1 \%$ glutaraldehyde in D-PBS for $15 \mathrm{~min}$ at $4{ }^{\circ} \mathrm{C}$, and tissue sections were washed three times in D-PBS for $10 \mathrm{~min}$ at room temperature. Bound cells were stained with $0.5 \%$ Toluidine blue in 20\% ethanol/PBS for $5 \mathrm{~min}$ at room temperature, and extensively washed with D-PBS. While sections were still wet, cover slips were mounted using 5\% gelatin in PBS. T cell adherence to RA synovial microvasculature was quantitated by counting the number of cells attached to the intravascular surface of at least 50 blood vessels each for two separate RA synovial sections per experiment. Values are expressed as average number of cells bound per blood vessel \pm SD.

\section{Results}

Generation of CS1-specific antibodies. To investigate the occurrence of alternatively spliced forms of FN containing the CS1 sequence, we generated a panel of six mAbs by immunization with a 12-amino acid peptide on the $\mathrm{COOH}$-terminal region of CS1 (see Methods). All of these mAbs bound to the intact 25-amino acid CS1 peptide (not shown), but more importantly, they exhibited well-defined sequence specificity as demonstrated by using a series of overlapping peptides to the CS1 region (Fig. $1 \mathrm{~A}$ ). The prototype mAb 90.45 bound to the COOH-terminal CS1 sequence (CS1-C-OVA conjugate), but not to either the $\mathrm{NH}_{2}$-terminal ( $\mathrm{CS} 1-\mathrm{N}-\mathrm{OVA}$ conjugate) or the middle portion of CS1 (CS1-M-OVA conjugate). This result, also obtained with the other five anti-CS1 mAbs, validates the strategy used for the immunization protocol. Anti-CS1 mAb 90.45 also recognized plasma $\mathrm{FN}$, but not other proteins such as OVA (Fig. $1 A$ ), BSA, gelatin, and laminin (not shown).

To confirm the sequence specificity of mAb 90.45 , peptide conjugates were used as soluble inhibitors of $\mathrm{mAb}$ binding to native CS1-coated ELISA plates (Fig. $1 \mathrm{~B}$ ). Only the peptide derived from the $\mathrm{COOH}$-terminal region of $\mathrm{CS} 1$ specifically inhibited binding of mAb 90.45 to native CS1 25-mer (Fig. $1 B$, filled circles). In summary, we have been able to generate a panel of CS1-specific mAbs that recognize both the CS1 peptide sequence alone, and also in the context of intact FN.

$R A$ synovial microvasculature differentially expresses alternatively spliced CS1. To study tissue expression of FN variants generated by alternatively splicing, immunohistochemistry was performed on synovial specimens obtained from both RA $(n=10)$ and normal $(n=6)$ individuals (Fig. 2). Sequential tissue sections from normal (Fig. 2, $a, c, e, g$, and $i$ ) and RA (Fig. 2, $b, d, f, h$, and $j$ ) synovia were incubated with a panel of mAbs followed by staining using the immunoperoxidase method. Identical experimental conditions were used for both RA and normal samples, i.e., same thickness sections, mounted on the same slide, incubated with the same concentration of primary and secondary antibody, and developed for the same length of time.

The specificity of the immunoperoxidase labeling technique was first demonstrated with mAb 4C7 (specific for the A chain of human laminin [40]), which stained distinctly the microvasculature of both normal and RA synovia (Fig. 2, $c$ and d). This result was consistent with laminin being localized to the subendothelial basement membrane (46). Expression of FN was then analyzed using mAb $3 E 3$, which reacts with a constant epitope on the cell attachment region of FN (41). Anti-FN mAb 3E3 uniformly stained endothelium and synovial extracellular space in both normal and RA synovia (Fig. 2, $e$ and $f$ ). This pattern of immunostaining was observed not only with $\mathrm{mAb} 3 \mathrm{E} 3$, but also with three additional FN framework epitope mAbs (not shown): namely, 3E1 (to the $\mathrm{COOH}$ terminal heparin binding region of $F N$ ), 4B2 (to the collagenbinding region of $F N$ ), and $F N-15$. Thus, both normal and RA tissue exhibit homogeneous immunoreactivity to FN mAbs throughout the interstitial synovial ECM.

In sharp contrast, RA sections labeled with anti-CS1 $\mathrm{mAb}$ 90.45 showed conspicuous staining in the endothelial lining of blood vessels (see Fig. $2 h$ ) and in the hyperplastic layers of the synovial intimal lining (see Fig. $3 e$ ), but not in the ECM. Moreover, CS1 immunostaining of RA microvasculature was seen with at least three additional independently derived antiCS1 mAbs (e.g., mAb 321; see Fig. $3 d$ ), and could be abrogated by pretreating mAb 90.45 with soluble CS1-C-OVA conjugate but not CS1-N-OVA or CS1-M-OVA (not shown), thus confirming the specificity of CS1 staining in RA. Fig. 2, $g$ and $h$, demonstrate a significant quantitative difference in blood vessel staining intensity with anti-CS1 $\mathrm{mAb}$ between representative RA and normal synovial tissues, the former being strongly positive $(10 / 10)$ and the latter being either weakly positive (1/6; see Fig. $2 g$ ) or completely negative (5/6). As for the intimal lining, CS1 was expressed in normal synovium on the single layer of lining cells (Fig. $2 \mathrm{~g}$, bottom right), whereas CS1 expression in RA spanned several layers of hyperplastic cells (not shown).

To address the possibility that normal synovial tissue may have impaired FN gene splicing, we investigated expression of FN containing alternatively spliced EIIIA, a domain that is typically found on cell-associated forms of FN $(1,42)$. Interestingly, both normal and RA synovial tissue exhibited approximately equal expression of EIIIA segment on both endothe- 


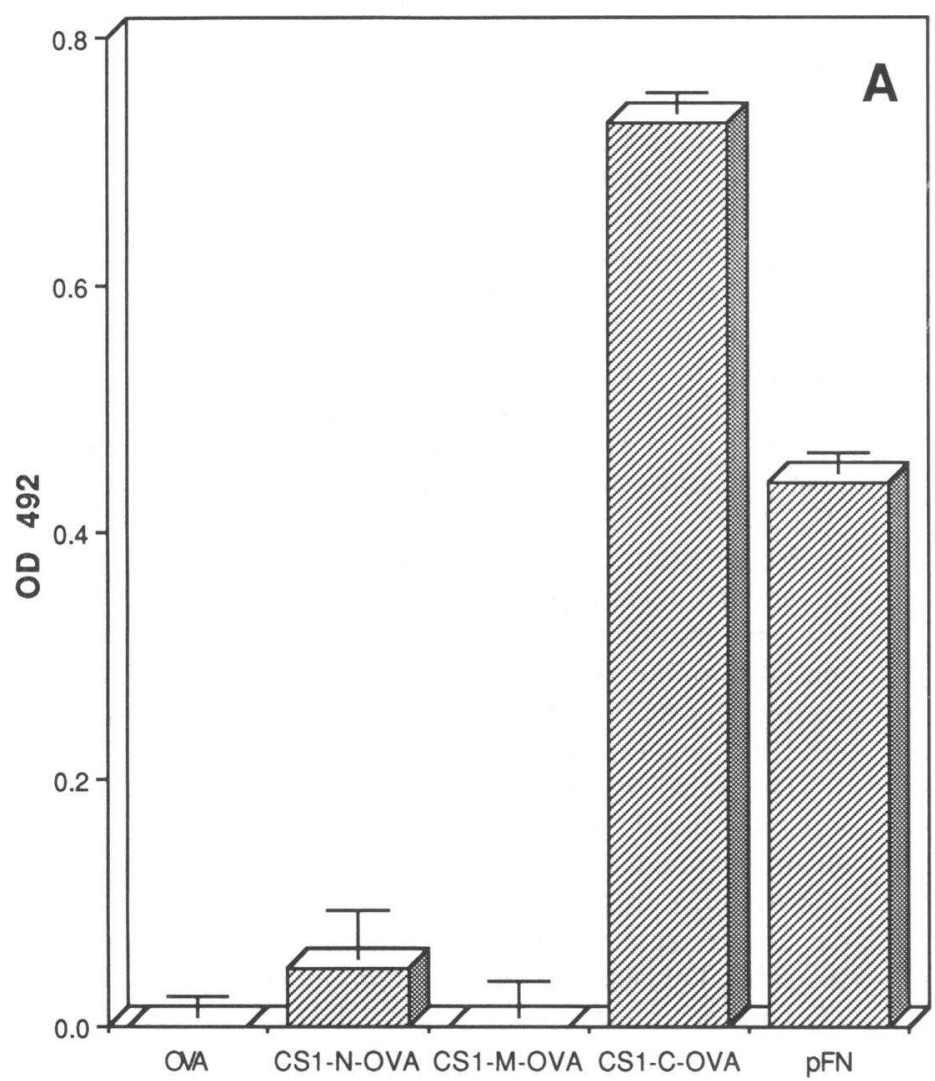

SUBSTRATE ON ELISA PLATE

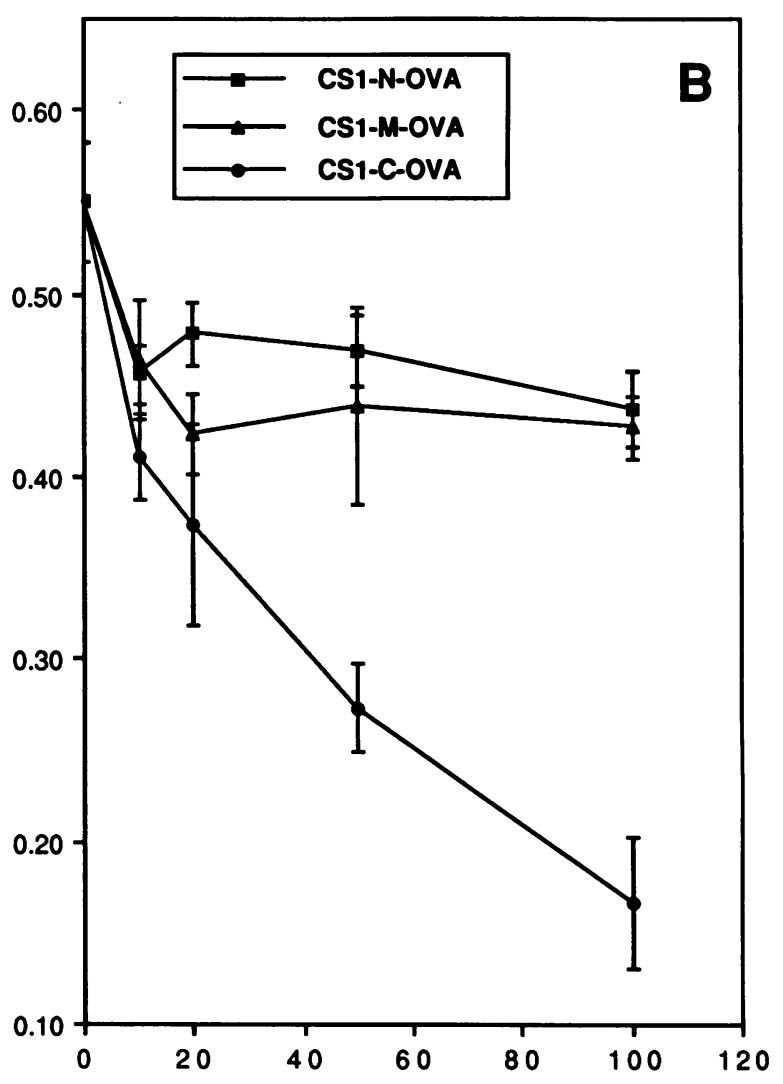

CONCENTRATION OF INHIBITOR $(\mu \mathrm{g} / \mathrm{ml})$

Figure 1. Specificity of anti-CS1 mAb 90.45. $(A)$ Immunoreactivity of mAb 90.45 was analyzed by an ELISA on microtiter plates coated with equimolar amounts of ovalbumin $(O V A), \mathrm{CS} 1$-ovalbumin conjugates spanning the entire 25-amino acid CS1 sequence (CSI-N-OVA, $C S 1$ - $M$ $O V A$, and $C S I-C-O V A$ ), and plasma FN $(p F N)$. (B) Inhibition of binding of mAb 90.45 to CS1-coated (25-mer) ELISA plates was tested by preincubating $\mathrm{mAb} 90.45$ with soluble peptide conjugates (same as above).

lium and ECM, as judged by labeling with mAb DH1 (Fig. 2, $i$ and $j$ ). Taken together, the results above strongly suggest that RA synovium selectively expresses CS1-containing FN in synovial blood vessels, and to some extent, in synovial intimal lining.

Alternatively spliced CS1 is expressed on the lumen of $R A$ endothelium. To determine the precise location of CS1-containing FN in RA endothelium, we performed transmission EM of RA synovial ultrathin sections stained by the immunoperoxidase technique. Incubation with control antibody showed no distinct labeling (Fig. $3 a$ ), but allowed visualization of the osmium-stained endothelial cell (EC) monolayer facing the lumen of the blood vessel with a red blood cell ghost in its proximity. In contrast, synovial tissue treated with mAbs to either PECAM-1 /CD31 (Fig. 3 b) or collagen type IV (Fig. 3 c) specifically stained discrete ultrastructural regions, namely, the lumenal aspect of the blood vessel endothelium (PECAM$1 / \mathrm{CD} 31$; Fig. $3 b$ ) and the subendothelial region (collagen type IV; Fig. $3 \mathrm{c}$ ). This pattern of immunoreactivity is consistent with PECAM-1/CD31 being an EC membrane marker (47), and collagen type IV being a major component of the basal lamina (46). Labeling of ultrathin synovial sections with the anti-CS1 mAb 321 (mAb 90.45 did not stain paraformaldehyde-fixed sections) showed distinct immunostaining on the lumenal plasma membrane of EC (Fig. $3 d$ ). In addition, anti$\mathrm{CS} 1$ also prominently stained the plasma membrane of synoviocytes in the synovial intimal lining (Fig. $3 e$ ), at the interface with the joint space. In sections in which membrane sloughing was observed, most of the immunoreactivity to CS1 was found within EC (Fig. $3 f$ ), but not within a neighboring macrophage, thus suggesting that EC in RA may generate CS1-containing FN intracellularly. This observation is consistent with the ability of cultured human EC to synthesize and secrete FN (48). In conclusion, CS1-expressing FN localizes to the lumen of EC and intimal lining synoviocytes, and could potentially mediate adhesion of circulating leukocytes within the RA synovial microvasculature.

Cultured human EC express CS1-containing FN $m R N A$. Expression of CS1-containing FN on the surface of EC in RA synovium raises questions about the cellular source of alternatively spliced CS1. To determine whether human EC are capable of expressing alternatively spliced FN mRNA that includes CS1, Northern blot analysis of human umbilical vein endothelial cell (HUVEC) mRNA was performed (Fig. $4 A$ ). Probes specific for CS1 (Fig. $4 A$, lane $b$ ) and HepII (one of the two conserved heparin-binding regions of FN [1]; lane $d$ ) both hybridized to an $\sim 8$-kb mRNA band present in IL- $\beta$-stimulated HUVEC. The apparent size of this mRNA species is in 

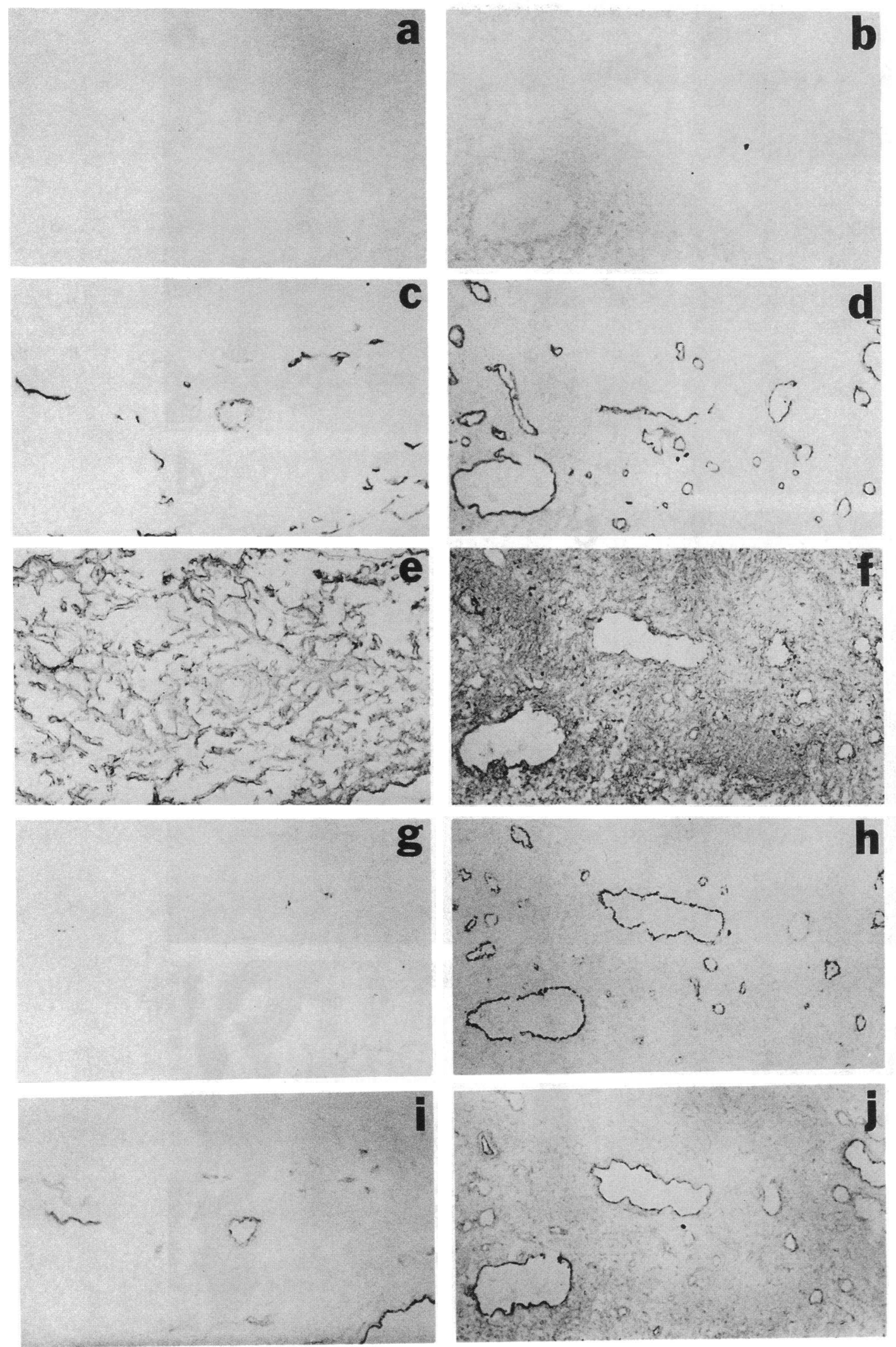

Figure 2. Immunoperoxidase staining of normal and RA synovial tissue sections. Normal $(a, c, e$, $g$, and $i)$ and RA $(b, d$, $f, h$, and $j$ ) synovial sections ( $5 \mu \mathrm{m}$ thick) were incubated with the following mAbs (at concentrations of $1-5 \mu \mathrm{g} / \mathrm{ml})$ : MOPC 104E ( $a$ and $b$ ), 4C7 (anti-human laminin A chain; $c$ and $d$ ), 3E3 (anti-human cell binding fragment of FN; $e$ and $f$ ), 90.45 (antihuman $\mathrm{COOH}$-terminal peptide sequence of $\mathrm{CS} 1$; $g$ and $h$ ), and DH 1 (anti-human alternatively spliced EIIIA fragment of $\mathrm{FN} ; i$ and $j$ ).

agreement with the expected 7.9-kb size of FN mRNA transcripts (1). In contrast to HUVEC, no 8-kb band was detected in mRNA obtained from the EBV-transformed human lymphoblastoid B cell line MAT-2 probed with either CS1 (Fig. 4
$A$, lane $a$ ), or HepII (lane $c$ ). Thus, CS1 is present in FN mRNA expressed in cytokine-stimulated HUVEC.

To independently confirm these observations, RNase protection assays were carried out using mRNA from IL- $1 \beta$ - 

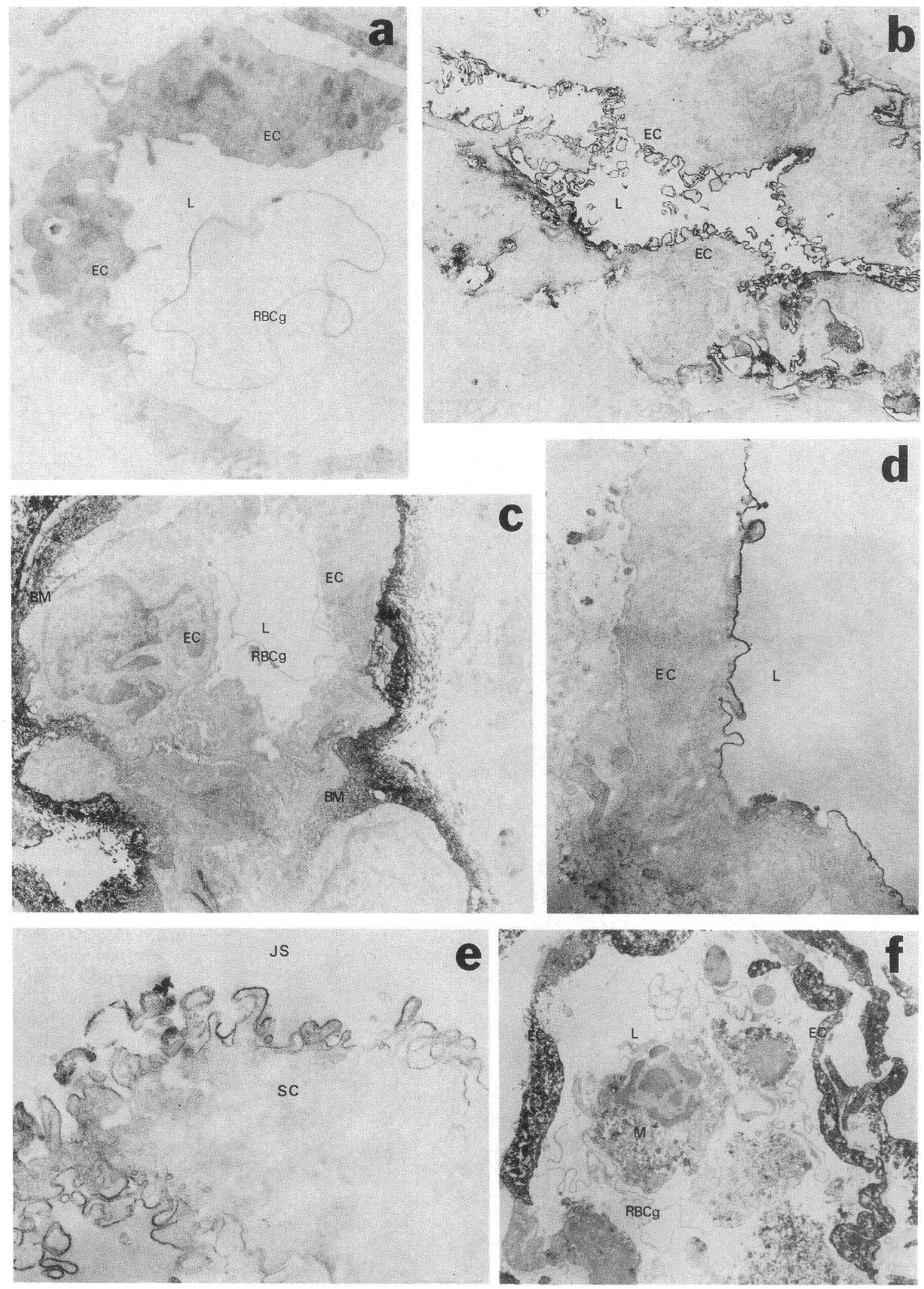

Figure 3. Transmission EM of ultrathin RA synovial sections after immunoperoxidase staining with mAbs. RA synovial tissue was stained with mAbs using the immunoperoxidase technique, and then ultrathin sections ( $500 \AA$ ) were visualized by transmission EM. mAbs used were as follows: control $(a)$, P1G12 (anti-human PECAM-1; $b$ ), mAb to human collagen type IV $(c), 321$ (anti-human COOH-terminal peptide sequence of $\mathrm{CS} 1 ; d, e$, and $f)$. 


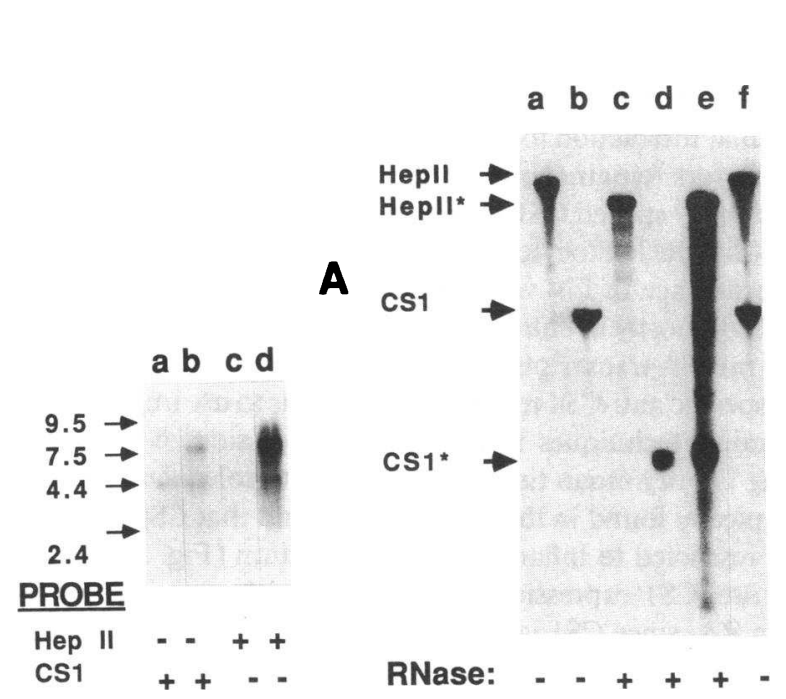

Figure 4. Cytokine-stimulated HUVEC express CS1-containing mRNA transcripts. $(A)$ Northern blot analyses of MAT-2 (lanes $a$ and $c$ ), and IL-1 $\beta$-treated HUVEC (lanes $b$ and $d$ ) mRNA after hybridization with either CS1 (lanes $a$ and $b$ ), or HepII (lanes $c$ and $d$ ) probes. $(B)$ Protection of RNA fragments from IL- $1 \beta$-stimulated HUVEC mRNA by riboprobes to either HepII (lanes $a$ and $c$ ), or CS1 (lanes $b$ and $d$ ), or both (lanes $e$ and $f$ ) with (lanes $c, d$, and $e$ ) or without (lanes $a, b$, and $f$ ) RNase digestion.

stimulated HUVEC (Fig. 4 B). Radiolabeled riboprobes complementary to HepII and CS1 coding strands were generated, and incubated with IL-1 $\beta$-stimulated HUVEC mRNA (see Methods). Upon treatment with RNase, only the portion of each probe specifically hybridized to mRNA is expected to remain undigested. Both probes also contained 76 bp of vectorderived flanking sequences that are noncomplementary, and thus RNase sensitive, to allow differentiation between fulllength undigested probe (see Fig. $4 B$, lanes $a, b$, and $f$ ) and protected RNA fragments (lanes $c, d$, and $e$ ). Assay products were resolved by denaturing polyacrylamide gel electrophoresis, and detection of protected fragments derived from both the HepII ( HepII*, lanes $c$ and $e$ ) and CS1 $\left(C S 1^{*}\right.$, lanes $d$ and $e$ ) probes clearly indicated the presence of CS1-expressing FN mRNA.

Taken together, expression of CS1-containing FN mRNA in HUVEC and EM immunostaining of RA synovium (see previous section ) are most consistent with endothelial cells in RA microvasculature being capable of synthesizing alternatively spliced CS1 and exporting CS1-expressing FN to the cell membrane.

CSI on RA endothelium mediates VLA-4-dependent lymphocyte adherence. To analyze the functional status of CS1 expressed on the lumenal surface of RA endothelial cells (see above), Stamper-Woodruff (45) adhesion assays were performed on frozen RA synovial sections. Initially, a panel of T lymphoblastoid cell lines were analyzed for their attachment properties on the CS1 25-amino acid sequence immobilized on plastic plates. Only Jurkat cells were found to bind efficiently to CS1, and, as expected, binding was inhibited by anti$\alpha 4$ mAbs (Fig. 5). In contrast, Molt-4 cells did not attach to CS1, unless cells were previously activated with adhesion-promoting mAb 8A2 $(39,49)$. Subsequently, Molt-4 attachment could also be inhibited by anti- $\alpha 4$ mAbs (Fig. 5). Taken to-

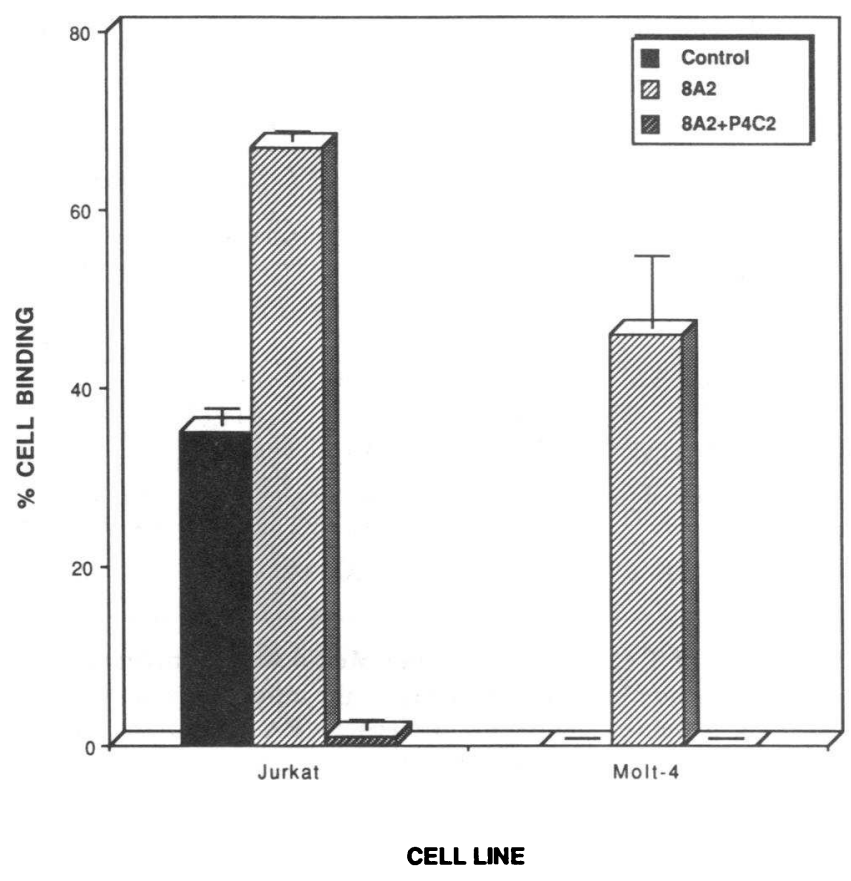

Figure 5. Adhesion of Jurkat and Molt-4 T lymphoblastoid cells to synthetic 25-amino acid CS1 peptide. Chromium-labeled Jurkat or Molt- 4 cells were incubated on microtiter plates coated with CS1 peptide (25-mer) as described previously (Elices et al., [23]). Inhibition of cell attachment by mAbs was analyzed using the following reagents: control mAb LB3.1 ( $1 \mu \mathrm{g} / \mathrm{ml}$; anti-human class II MHC), P4C2 $(0.6 \mu \mathrm{g} / \mathrm{ml}$; anti-human $\alpha 4$ integrin subunit), and 8A2 $(1 \mu \mathrm{g} /$ $\mathrm{ml}$; anti-human $\beta 1$ integrin subunit).

gether, these results confirm the observation that functional activation of VLA-4 is required for cell adhesion to CS1 (39, 49-52).

Both Jurkat ( $n=5$; Table I and Fig. 6), and Molt-4 $(n=3$; Table I and Fig. 7) were then assayed for cell adherence on frozen RA synovial sections. Unstimulated Jurkat readily bound to the lumenal aspect of blood vessels in RA synovium, with little interstitial cell binding (Fig. $6 a$ ). Attachment of Jurkat cells to RA intimal synovial lining was also observed (not shown). In contrast, Jurkat cells failed to adhere to synovial blood vessels from normal tissue specimens $(>2 \pm 1 \mathrm{~T}$ cells bound/blood vessel; $n=2$; not shown).

mAb inhibition experiments (see Table I) showed that Jurkat intravascular adhesion was abrogated by anti- $\alpha 4 \mathrm{mAb}$ P4C2 $(3 \mu \mathrm{g} / \mathrm{ml}$; Table I and Fig. $6 b)$, and dramatically reduced by the CS1 peptide ( $500 \mu \mathrm{g} / \mathrm{ml}$; Table I and Fig. $6 c$ ). In addition, we found that anti-CS1 mAb 90.45 was also inhibitory in this assay (not shown). Jurkat cell binding was relatively unaffected, however, by incubation of RA sections with at least two separate mAbs to VCAM-1, namely 4B9 (10-20 $\mu \mathrm{g} / \mathrm{ml}$; this mAb blocks VLA-4-dependent adhesion to both six- and seven-Ig domain forms of VCAM-1) $(37,38)$ and P3H12 $(10-20 \mu \mathrm{g} / \mathrm{ml})$ (see Table I and Fig. $6 d$ ). Neither control peptide $(500 \mu \mathrm{g} / \mathrm{ml})$, nor scrambled CS1 peptide ( 500 $\mu \mathrm{g} / \mathrm{ml})$ or anti- $\alpha 5 \mathrm{mAb}$ P1D6 $(10-20 \mu \mathrm{g} / \mathrm{ml})$, had any effect on Jurkat adhesion to RA synovium ( Table I). To ensure that lack of inhibition by anti-VCAM-1 was not due to epitope loss during tissue preparation, RA synovial sections from tissue specimens used in binding assays were stained with mAbs 4B9 
Table I. Adhesion of T Cells to the Microvasculature of $R A$ Synovium

\begin{tabular}{lccccr}
\hline & \multicolumn{4}{c}{ T cell adhesion* } \\
\cline { 2 - 4 } \multicolumn{1}{c}{ Incubation } & \multicolumn{2}{c}{ Jurkat } & & \multicolumn{2}{c}{ Molt-4 $^{*}$} \\
\cline { 2 - 3 } \cline { 5 - 6 } & Exp. 1 & Exp. 2 & & Exp. 1 & Exp. 2 \\
\hline Control Ab & $11 \pm 4$ & $14 \pm 3$ & $0 \pm 0$ & $0 \pm 0$ \\
Stimulating Ab & - & - & & $14 \pm 4$ & $19 \pm 5$ \\
Anti-VLA-4 & $0.5 \pm 0$ & $1 \pm 0$ & $1 \pm 0.5$ & $2 \pm 1$ \\
Anti-VLA-5 & $10 \pm 3$ & $12 \pm 4$ & $11 \pm 3$ & $18 \pm 4$ \\
Anti-VCAM-1-A & $12 \pm 5$ & $12 \pm 5$ & $17 \pm 6$ & $21 \pm 8$ \\
Anti-VCAM-1-B & $11 \pm 5$ & $14 \pm 5$ & $12 \pm 5$ & $17 \pm 6$ \\
CS1 peptide & $2 \pm 1$ & $3 \pm 1$ & $3 \pm 1$ & $4 \pm 2$ \\
CS1 scrambled & $11 \pm 3$ & $15 \pm 2$ & $13 \pm 3$ & $20 \pm 4$ \\
& & & & \\
\hline
\end{tabular}

* Adhesion of $\mathrm{T}$ cell lines Jurkat and Molt-4 was quantitated by counting the number of cells attached to the intravascular surface of at least 50 blood vessels each for two separate RA synovial sections per experiment. Values are expressed as average number of cells bound/blood vessel $\pm S D$. $m A$ bs used in inhibition experiments were: control, LB3.1 to MHC class II antigens; anti-VLA-4, P4C2 (15); anti-VLA-4, P1D6 (15); anti-VCAM-1-A, P3H12 (36); anti-VCAM1-B, 4B9 $(24,37,38) .{ }^{\ddagger}$ All these incubations were performed with Molt-4 cells subjected to activation by prior treatment with adhesion-stimulating mAb 8A2 (39). ${ }^{8}$ The sequence of the CS1 peptide is GPEILDVPST. "The sequence of the scrambled CS1 peptide is VIPDLTESPG.

and $\mathrm{P} 3 \mathrm{H} 12$, and positive VCAM-1 immunoreactivity was found unaltered (not shown). As an additional control, antiVCAM-1 mAbs 4B9 and P3H12 did inhibit adhesion of Jurkat cells to germinal centers from monkey mesenteric lymph nodes (not shown), in agreement with published reports (53).

Similar experiments using unstimulated Molt-4 cells indicated that Molt- 4 did not adhere to the lumen of RA synovial blood vessels ( Table I and Fig. $7 a$ ), unless cells were pretreated with adhesion-promoting mAb 8A2 (Table I and Fig. $7 b$ ). mAb-stimulated adherence of Molt- 4 cells to RA synovial endothelium was then inhibitable by anti- $\alpha 4$ and by CS1 peptide (Table I and Fig. $7 c$ ), but not by control peptides (Table I), by anti-VCAM-1 mAbs (Table I and Fig. $7 d$ ), or by anti- $\alpha 5$ (Table I). In conclusion, adherence of $T$ cell lines to the endothelium in RA synovium requires functional activation of VLA-4, and is primarily mediated by CS1 on RA EC.

\section{Discussion}

We have investigated the expression and functional significance of CS1-containing forms of FN generated by alternatively splicing in both normal and RA synovium. Our data suggest that RA, but not normal, synovial endothelium selectively expresses CS1. Quite unexpectedly, CS1-expressing FN molecules are found decorating the lumen of RA EC, but are totally absent on the abluminal side of the endothelium and in the ECM. Functionally, endothelial expression of CS1 in RA synovium results in intravascular adherence of activated $T$ lymphocytes in both a VLA-4- and CS1-dependent fashion. These observations provide a basis for attempting to interfere with chronic accumulation of mononuclear cells in RA using CS1-based therapeutics.
To date, much of the work on FN polypeptide diversity and regulation of FN gene splicing patterns has focused largely on the EIIIA and EIIIB regions $(5-9,42)$. However, a specific molecular interaction for either EIIIA or EIIIB and target cellular receptors remains to be defined. In contrast, expression of alternatively spliced CS1 results in generation of a binding site on FN for the leukocyte integrin VLA-4 $(15,16)$. Previously, the occurrence of FN variants expressing CS1 had only been surmised, mostly in cultured cell lines, by analyzing the cohort of FN mRNA transcripts (2-4, 10-12). In this study, availability of specific anti-CS1 mAbs has allowed us to use immunohistochemical techniques to investigate expression of CS1-containing FN in human tissues. Unlike most molecular forms of FN typically found in the ECM (1), we find that CS1 is exclusively restricted to inflamed RA endothelium (Fig. $2 h$ ). Furthermore, CS1 expression correlates with chronic inflammation in RA, since CS1 is found only rarely in normal synovial blood vessels (Fig. $2 \mathrm{~g}$ ). CS1 immunoreactivity in RA synovium appears to be specific for this $\mathrm{FN}$ variant because a panel of mAbs, four to conserved epitopes on FN (41) and one mapping to the EIIIA region $(1,42)$, all stain the ECM on both RA and normal synovium. Thus, our data strongly suggest that CS1-containing FN is specifically expressed on blood vessel endothelium, but not in the ECM, and CS1 expression correlates with the inflammatory phenotype in RA synovium.

By and large, FN is considered to be an ECM component involved in tissue organization, differentiation, and repair, even though FN can also be found in circulating plasma and other body fluids (1). Thus, lumenal expression of CS1-containing FN on EC and also synoviocytes in the intimal lining of RA synovium as shown by immunoelectron microscopy (see Fig. 3, $d$ and $e$ ) is totally unexpected. Indeed, the endothelium is known to modulate leukocyte emigration and trafficking, especially during inflammation, through expression of a select group of cytokine-inducible transmembrane adhesion molecules, namely intercellular adhesion molecule type 1 (ICAM1), ICAM-2, VCAM-1, and E- and P-selectins (26, 54, 55). To our knowledge, this is the first suggestion that a matrix protein like FN may play a direct role in recruitment of circulating leukocytes to inflamed endothelium via alternatively spliced CS1.

Since alternative splicing of $\mathrm{FN}$ is a process of considerable biological significance, especially during embryogenesis $(5,6$, 42 ), the observation that CS1 is selectively expressed in RA synovium suggests functional involvement for CS1 in the pathogenesis of RA. In this regard, the T cell line Jurkat was found to adhere readily to the intravascular surface of RA synovial endothelium (see Fig. $6 a$ ). Based on inhibition data (see Table I), T cell attachment appears to be mediated by the integrin VLA-4 on the lymphocyte (see Fig. $6 b$ ) interacting with a putative CS1-containing counterreceptor on the endothelial cell (see Fig. $6 \mathrm{c}$ ). Since Jurkat adhesion to RA synovium is blocked by CS1 peptide and anti-CS1 mAb, but not by mAbs to VCAM-1 (see Table I and Fig. 6, $c$ and $d$ ), we conclude that a direct interaction occurs between lymphocyte VLA-4 and CS1-containing FN expressed on RA microvasculature.

Our data also suggest that functional activation of VLA-4 is required for efficient $T$ cell binding to RA endothelium. While Jurkat cells express a partially activated form of VLA-4 (Fig. 5 ), a separate T cell line, Molt-4, expresses VLA-4 in a functionally inactive state (Fig. 5), and thus is incapable of binding to RA synovium (Fig. 7 a). Incubation of Molt-4 with an adhesion-stimulating $\mathrm{mAb}$, such as $8 \mathrm{~A} 2$, shifts VLA-4 into a func- 

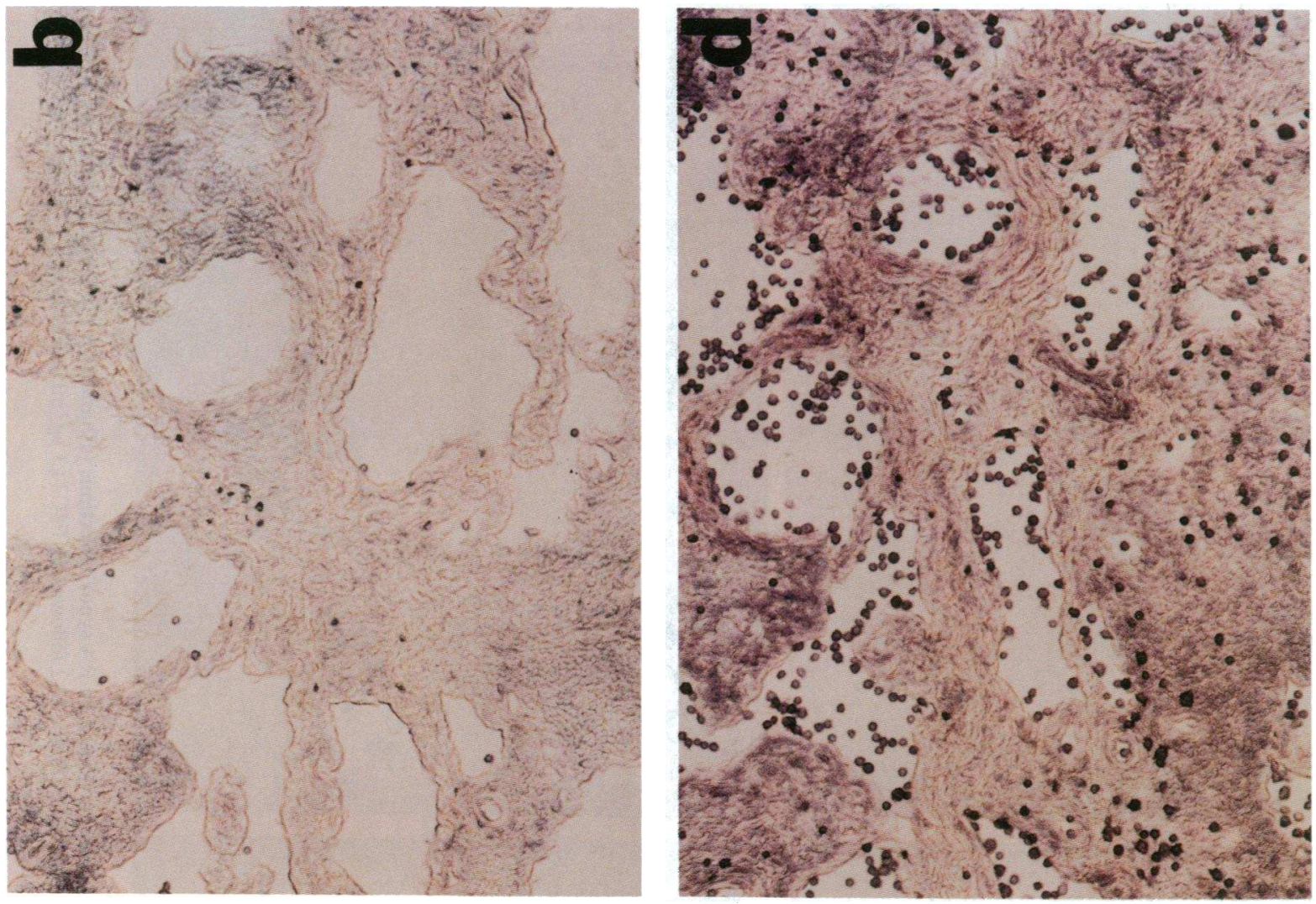

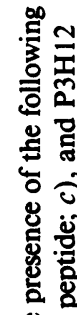
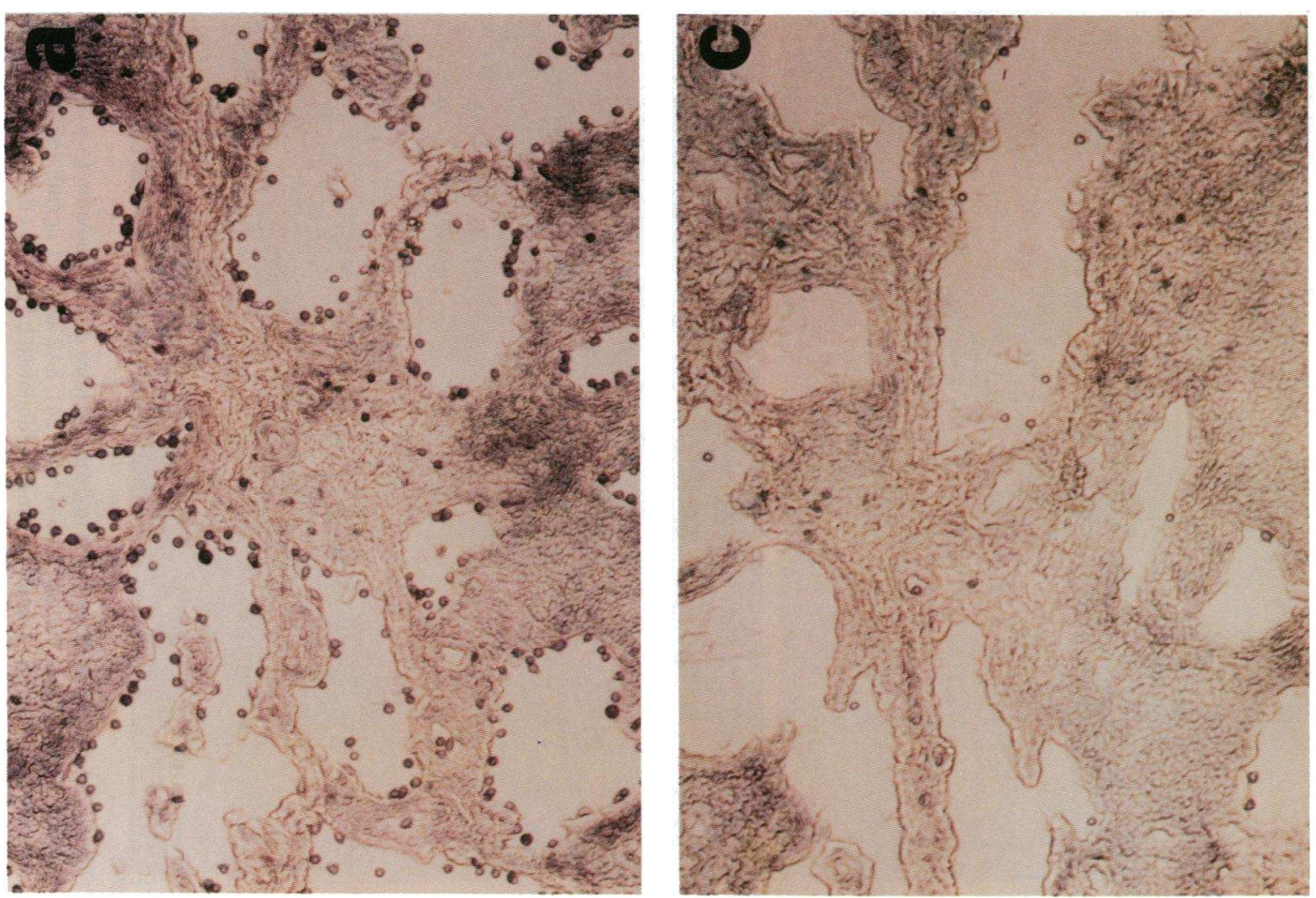

苋:

至

윯

बू

ลิ่

๙

ธ율

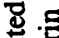

苛 

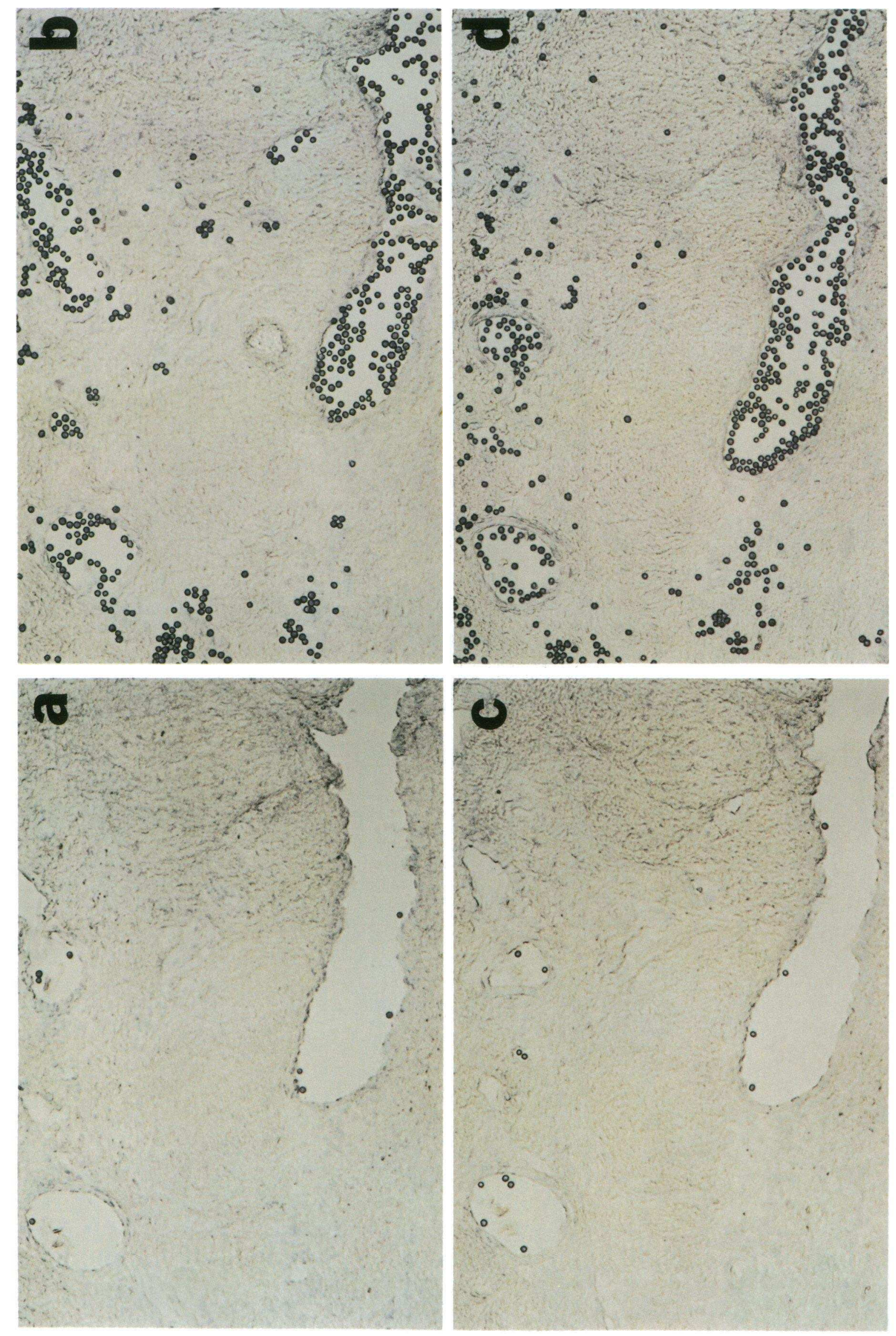

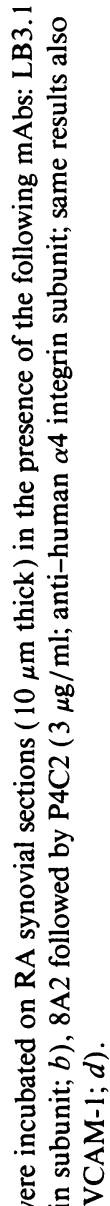

号 율

可高

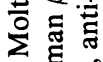

穴豆

11. $\frac{1}{1}$ को

5 요

घี है

政

可

元

중

这

ㅎํㅇㅎㅇ

论

远就

웅

氖

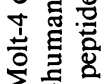

出

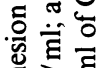

部

$\therefore \simeq 8$

등 \&

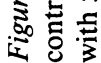


tionally activated state $(39,49-52)$, and this results jus drati: matic augmentation of Molt-4 adherence to RA endothelium (Fig. $7 \mathrm{~b}$ ). mAb-stimulated attachment of Molt-4, like that of unstimulated Jurkat cells, is then inhibited by both anti-VLA-4 and CS1 peptide, but remains unaffected by mAbs to VCAM-1 (see Table I and Figs. 7, $c$ and $d$ ). Consequently, T cell adherence to RA endothelium requires prior functional activation of leukocyte VLA-4, and is mediated by CS1 present on the lumen of RA endothelial cells. In this regard, our results correlate nicely with analyses on the functional status of VLA-4 on T cells isolated from the synovial fluid and synovial membrane of RA patients $(56,57)$. These $T$ lymphocytes exhibit increased VLA-4-mediated adherence to both CS1 (56) and VCAM-1 (57) relative to autologous peripheral blood lymphocytes. These studies $(56,57)$, as well as ours, suggest that only leukocytes expressing functionally activated VLA-4 are selectively recruited to inflammatory sites in RA.

The involvement of VLA-4 in functional interactions between leukocytes and RA synovium raises the question of which role VLA-4 ligands, i.e., CS1 and VCAM-1, play in the pathogenesis of RA. To date, most studies have focused on expression of VCAM-1 in RA $(36,58,59)$. VCAM-1 has been found in RA synovial microvasculature $(36,58)$, and in cultured fibroblast-like synoviocytes (FLS) derived from RA patients $(36,59)$. However, we have shown that small amounts of VCAM-1 are also expressed in normal synovial endothelium (36). With regard to the functional status of VCAM-1 on RA endothelium, in vitro studies have shown that anti-VCAM-1 partially inhibits both lymphocyte adherence to synovial high endothelial venules (58), and adhesion of T cell lines to IL-1and IL-4-stimulated FLS from RA patients (36). This study clearly indicates involvement of CS1, but not VCAM-1, in lymphocyte attachment to frozen sections from synovial specimens with clinical characteristics of full-fledged RA. Since cytokines are known to induce transient expression of VCAM-1 in RA $(36,59)$, it is conceivable that local and temporal changes in cytokine production within the rheumatoid joint may dictate which pathway, VLA-4/VCAM-1 or VLA-4/CS1, predominantly operates at a given stage in synovitis. Recently, leukocyte integrins, including VLA-4, have also been implicated in monocyte recruitment in RA (60).

Expression of CS1-containing FN in RA raises the possibility that CS1, and consequently FN gene splicing, may be subject to regulation by inflammatory stimuli. In this regard, transforming growth factor $\beta$ has been shown to influence splicing $(61,62)$ and polarized secretion of FN (62). This study shows that IL- $1 \beta$-stimulated HUVEC are capable of generating splicing variants of FN containing $C S 1$, and we have also observed that treatment with IL- $1 \beta$ may upregulate CS1containing FN mRNA in HUVEC monolayers (Goel, A. S., et al., unpublished data). In addition, we have recently found selective expression of CS1 on endothelium at inflammatory sites in the skin, lung, and gut, attesting to the potentially widespread upregulation of CS1 in chronic inflammation (Elices, M. J., et al., unpublished observations).

In summary, we have shown that CS1-positive variants of FN are selectively expressed on RA synovial endothelium and may be functionally active in mediating VLA-4-dependent lymphocyte adherence. Consequently, CS1-expressing FN may play a dominant role in specific recruitment and retention of mononuclear leukocytes in RA synovium, and thus suggests a potential means for therapeutic intervention.

\section{Acknowledgments}

We gratefully acknowledge Drs. B. Chesnut, H. Grey, J. Harlan, N. Kovach, J. Kranzler, L. Phillips, J. Paulson, A. Sette, S. Sobin, and L. Vollger for contributing reagents and for many helpful suggestions. We also thank David Boyle, Ellen Narva, Carla Oseroff, and Bill Way for expert technical assistance.

This work was supported in part by National Institutes of Health grants AR-40525 and AR-39576 (to G. S. Firestein), and by Cytel Corporation.

\section{References}

1. Hynes, R. O. 1990. Fibronectins. Springer Publishing Company, New York. $546 \mathrm{pp}$

2. Schwarzbauer, J. E., J. W. Tamkun, I. R. Lemischka, and R. O. Hynes. 1983. Three different fibronectin mRNAs arise by alternative splicing within the coding region. Cell. 35:421-431.

3. Kornblihtt, A. R., K. Vibe-Pedersen, and F. E. Baralle. 1984. Human fibronectin: cell specific alternative mRNA splicing generates polypeptide chains differing in the number of internal repeats. Nucleic Acids Res. 12:5853-5868.

4. Sekiguchi, K., A. M. Klos, K. Kurachi, S. Yoshitake, and S. Hakomori. 1986. Human liver fibronectin complementary DNAs: identification of two different messenger RNAs possibly encoding the $\alpha$ and $\beta$ subunits of plasma fibronectin. Biochemistry. 25:4936-4941.

5. ffrench-Constant, C., and R. O. Hynes. 1988. Patterns of fibronectin gene expression and splicing during cell migration in chicken embryos. Development (Camb.). 104:369-382.

6. ffrench-Constant, C., and R. O. Hynes. 1989. Alternative splicing of fibronectin is temporally and spatially regulated in the chicken embryo. Development (Camb.). 106:375-388.

7. ffrench-Constant, C., L. Van De Water, H. F. Dvorak, and R. O. Hynes. 1989. Reappearance of an embryonic pattern of fibronectin splicing during wound healing in the adult rat. J. Cell Biol. 109:903-914.

8. Norton, P. A., and R. O. Hynes. 1987. Alternative splicing of chicken fibronectin in embryos and in normal and transformed cells. Mol. Cell. Biol. 7:4297-4307.

9. Magnuson, V. L., M. Young, D. G. Schattenberg, M. A. Mancini, D. Chen, B. Steffensen, and R. J. Klebe. 1991. The alternative splicing of fibronectin premRNA is altered during aging and in response to growth factors. J. Biol. Chem. 266:14654-14662.

10. Tamkun, J. W., J. E. Schwarzbauer, and R. O. Hynes. 1984. A single rat fibronectin gene generates three different mRNAs by alternative splicing of a complex exon. Proc. Natl. Acad. Sci. USA. 81:5140-5144.

11. Vibe-Pedersen, K., S. Magnusson, and F. E. Baralle. 1987. Donor and acceptor splice signals within an exon of the human fibronectin gene -a new type of differential splicing. FEBS (Fed. Eur. Biol. Soc.) Lett. 207:287-291.

12. Hershberger, R. P., and L. A. Culp. 1990. Cell-type-specific expression of alternatively spliced human fibronectin IIICS mRNAs. Mol. Cell. Biol. 10:662671.

13. Humphries, M. J., S. K. Akiyama, A. Komoriya, K. Olden, and K. M. Yamada. 1986. Identification of an alternatively spliced site in human plasma fibronectin that mediates cell type-specific adhesion. J. Cell Biol. 103:26372647.

14. Humphries, M. J., A. Komoriya, S. K. Akiyama, K. Olden, and K. M. Yamada. 1987. Identification of two distinct regions of the type III connecting segment of human plasma fibronectin that promote cell type-specific adhesion. $J$. Biol. Chem. 262:6886-6892.

15. Wayner, E. A., A. Garcia-Pardo, M. J. Humpries, J. A. McDonald, and W. G. Carter. 1989. Identification and characterization of the T lymphocyte adhesion receptor for an alternative cell attachment domain (CS-1) in plasma fibronectin. J. Cell Biol. 109:1321-1330.

16. Guan, J.-L., and R. O. Hynes. 1990. Lymphoid cells recognize an alternatively spliced segment of fibronectin via the integrin receptor $\alpha 4 \beta 1$. Cell. 60:5361.

17. Hemler, M. E. 1990. VLA proteins in the integrin family: structures, functions, and their role on leukocytes. Annu. Rev. Immunol. 8:365-400.

18. Williams, D. A., M. Rios, C. Stephens, and V. P. Patel. 1991. Fibronectin and VLA-4 in hematopoietic stem cell-microenvironment interactions. Nature (Lond.). 352:438-441.

19. Roldan, E., A. Garcia-Pardo, and J. A. Brieva. 1992. VLA-4-fibronectin interaction is required for the terminal differentiation of human bone marrow cells capable of spontaneous and high rate immunoglobulin secretion. J. Exp. Med. 175:1739-1747.

20. Sawada, M., J. Nagamine, K. Takeda, K. Utsumi, A. Kosugi, Y. Tatsumi, T. Hamaoka, K. Miyake, K. Nakajima, T. Watanabe, S. Sakakibara, S., and H. Fujiwara. 1992. Expression of VLA-4 on thymocytes -maturation stage-asso- 
ciated transition and its correlation with their capacity to adhere to thymic stromal cells. J. Immunol. 149:3517-3524.

21. Utsumi, K., M. Sawada, S. Naruyima, J. Nagamine, T. Sakata, S. Iwagami, Y. Kita, H. Teraoka, H. Hirano, M. Ogata, T. Hamaoka, and H. Fujiwara. 1991. Adhesion of immature thymocytes to thymic stromal cells through fibronectin molecules and its significance for the induction of thymocyte differentiation. Proc. Natl. Acad. Sci. USA. 88:5685-5689.

22. Dufour, S., J.-L. Duband, M. J. Humphries, M. Obara, K. M. Yamada, and J. P. Thiery. 1988. Attachment, spreading and locomotion of avian neural crest cells are mediated by multiple adhesion sites on fibronectin molecules. EMBO (Eur. Mol. Biol. Organ.) J. 7:2661-2671.

23. Elices, M. J., L. Osborn, Y. Takada, C. Crouse, S. Luhowskyj, M. E. Hemler, and R. R. Lobb. 1990. VCAM-1 on activated endothelium interacts with the leukocyte integrin VLA-4 at a site distinct from the VLA-4/fibronectin binding site. Cell. 60:577-584.

24. Schwartz, B. R., E. A. Wayner, T. M. Carlos, H. D. Ochs, and J. M. Harlan. 1990. Identification of surface proteins mediating adherence of CD11/ CD18-deficient lymphoblastoid cells to cultured human endothelium. J. Clin. Invest. 85:2019-2022.

25. Hemler, M. E., M. J. Elices, C. Parker, and Y. Takada. 1990. Structure of the integrin VLA-4 and its cell-cell and cell-matrix adhesion functions. Immunol. Rev. 114:45-65.

26. Osborn, L. 1990. Leukocyte adhesion to endothelium in inflammation. Cell. 62:3-6.

27. Ferguson, T. A., H. Mizutani, and T. S. Kupper. 1991. Two integrin-binding peptides abrogate $\mathrm{T}$ cell-mediated immune responses in vivo. Proc. Natl. Acad. Sci. USA. 88:8072-8076.

28. Pitzalis, C., G. Kingsley, J. Murphy, and G. Panayi. 1987. Abnormal distribution of the helper-inducer and suppressor-inducer T-lymphocyte subsets in the rheumatoid joint. Clin. Immunol. Immunopathol. 45:252-258.

29. Pitzalis, C., G. Kingsley, D. Haskard, and G. Panayi. 1988. The preferential accumulation of helper-inducer T lymphocytes in inflammatory lesions: evidence for regulation by selective endothelial and homotypic adhesion. Eur. $J$. Immunol. 18:1397-1404.

30. Lasky, H. P., K. Bauer, and R. M. Pope. 1988. Increased helper inducer and decreased suppressor inducer phenotypes in the rheumatoid joint. Arthritis Rheum. 31:52-59.

31. Firestein, G. S., V. Tsai, and N. J. Zvaifler. 1987. Cellular immunity in the joints of patients with rheumatoid arthritis and other forms of chronic synovitis. Rheum. Dis. Clinics North Am. 13:191-213.

32. Harris, E. D. 1990 . Rheumatoid arthritis: pathophysiology and implications for therapy. N. Engl. J. Med. 322:1277-1289.

33. Firestein, G. S., W.-D. Xu, K. Townsend, D. Broide, J. Alvaro-Gracia, A. Glasebrook, and N. J. Zvaifler. 1988. Cytokines in chronic inflammatory arthritis. I. Failure to detect $T$ cell lymphokines (interleukin 2 and interleukin 3 ) and presence of macrophage colony-stimulating factor (CSF-1) and a novel mast cell growth factor in rheumatoid synovitis. J. Exp. Med. 168:1573-1586.

34. Firestein, G. S., J. M. Alvaro-Gracia, and R. Maki. 1990. Quantitative analysis of cytokine gene expression in rheumatoid arthritis. J. Immunol. 144:3347-3353.

35. Arnett, F. C., S. M. Edworthy, D. A. Bloch, D. J. McShane, J. F. Fries, N. S. Cooper, L. A. Healey, S. R. Kaplan, M. H. Liang, H. S. Luthra, et al. 1988. The American Rheumatism Association 1987 revised criteria for the classification of rheumatoid arthritis. Arthritis Rheum. 31:315-324.

36. Morales-Ducret, J., E. Wayner, M. J. Elices, J. M. Alvaro-Gracia, N. J. Zvaifler, and G. S. Firestein. 1992. Alpha4/betal integrin (VLA-4) ligands in arthritis. I. Vascular cell adhesion molecule-1 expression in synovium and on fibroblast-like synoviocytes. J. Immunol. 149:1424-1431.

37. Osborn, L., C. Vassallo, C., and C. D. Benjamin. 1992. Activated endothelium binds lymphocytes through a novel binding site in the alternatively spliced domain of vascular cell adhesion molecule-1. J. Exp. Med. 176:99-107.

38. Vonderheide, R. H., and T. A. Springer. 1992. Lymphocyte adhesion through very late antigen 4: evidence for a novel binding site in the alternatively spliced domain of vascular cell adhesion molecule 1 and an additional $\alpha 4$ integrin counterreceptor on stimulated endothelium. J. Exp. Med. 175:1433-1442.

39. Kovach, N. L., T. M. Carlos, E. Yee, and J. M. Harlan. 1992. A monoclonal antibody to $\beta 1$ integrin (CD29) stimulates VLA-4-dependent adherence of leukocytes to human umbilical vein endothelial cells and matrix components. $J$. Cell Biol. 116:499-509.

40. Engvall, E., G. E. Davis, K. Dickerson, E. Ruoslahti, and M. Manthorpe.
1986. Mapping of domains of human laminin using monoclonal antibodies: localization of the neurite-promoting site. J. Cell Biol. 103:2457-2465.

41. Pierschbacher, M. D., E. G. Hayman, and E. Ruoslahti. 1981. Location of the cell-attachment site in fibronectin with monoclonal antibodies and proteolytic fragments of the molecule. Cell. 26:259-267.

42. Vartio, T., L. Laitinen, O. Narvanen, M. Cutolo, L.-E. Thornell, L. Zardi, and I. Virtanen. 1987. Differential expression of the ED sequence-containing form of cellular fibronectin in embryonic and adult human tissues. J. Cell Sci. 88:419-430.

43. McLean, I. W., and P. K. Nakane. 1974. Periodate-lysine-paraformaldehyde fixative: a new fixative for immunoelectron microscopy. J. Histochem. Cytochem. 22:1077-1083.

44. Sambrook, J., E. Fritsch, and T. Maniatis. 1989. Molecular Cloning: A Laboratory Manual. 2nd ed. Cold Spring Harbor Laboratory Press, Cold Spring Harbor, NY.

45. Stamper, H. B., and J. J. Woodruff. 1976. Lymphocyte homing into lymph nodes: in vitro demonstration of the selective affinity of recirculating lymphocytes for high-endothelial venules. J. Exp. Med. 144:828-833.

46. Martin, G. R., and R. Timpl. 1987. Laminin and other basement membrane components. Annu. Rev. Cell Biol. 3:57-85.

47. Muller, W. A., C. M. Ratti, S. L. McDonnell, and Z. A. Cohn. 1989. A human endothelial cell-restricted, externally disposed plasmalemmal protein enriched in intercellular junctions. J. Exp. Med. 170:399-414.

48. Jaffe, E. A., and D. F. Mosher. 1978. Synthesis of fibronectin by cultured human endothelial cells. J. Exp. Med. 147:1779-1791.

49. Wayner, E. A., and N. L. Kovach. 1992. Activation-dependent recognition by hematopoietic cells of the $\mathrm{LDV}$ sequence in the $\mathrm{V}$ region of fibronectin. $J$. Cell Biol. 116:489-497.

50. van de Wiel-van Kemenade, E., Y. van Kooyk, A. J. de Boer, R. J. F. Huijbens, P. Weder, W. van de Kasteele, C. J. M. Melief, and C. G. Figdor. 1992 Adhesion of $\mathrm{T}$ and $\mathrm{B}$ lymphocytes to extracellular matrix and endothelial cells can be regulated through the $\beta$ subunit of VLA. J. Cell Biol. 117:461-470.

51. Arroyo, A. G., P. Sanchez-Mateos, M. R. Campanero, I. Martin-Padura, E. Dejana, and F. Sanchez-Madrid. 1992. Regulation of the VLA integrin-ligand interactions through the $\beta 1$ subunit. J. Cell Biol. 117:659-670.

52. Masumoto, A., and M. E. Hemler. 1993. Multiple activation states of VLA-4. (Mechanistic differences between adhesion to CS1/fibronectin and to vascular cell adhesion molecule-1.) J. Biol. Chem. 268:228-234.

53. Freedman, A. S., M. J. Munro, G. E. Rice, M. P. Bevilacqua, C. Morimoto, B. W. McIntyre, K. Rhynhart, J. S. Pober, and L. M. Nadler. 1990. Adhesion of human B cells to germinal centers in vitro involves VLA-4 and INCAM110. Science (Wash. DC). 249:1030-1033.

54. Springer, T. A. 1990. Adhesion receptors of the immune system. Nature (Lond.). 346:425-434.

55. Butcher, E. C. 1991. Leukocyte-endothelial cell recognition: three (or more) steps to specificity and diversity. Cell. 67:1033-1036.

56. Laffon, A., R. Garcia-Vicuna, A. Humbria, A. A. Postigo, A. L. Corbi, M. O. de Landazuri, and F. Sanchez-Madrid. 1992. Upregulated expression and function of VLA-4 fibronectin receptors on human activated T cells in rheumatoid arthritis. J. Clin. Invest. 88:546-552.

57. Postigo, A. A., R. Garcia-Vicuna, F. Diaz-Gonzalez, A. G. Arroyo, M. O. De Landazuri, G. Chi-Rosso, R. R. Lobb, A. Laffon, and F. Sanchez-Madrid. 1992. Increased binding of synovial $T$ lymphocytes from rheumatoid arthritis to endothelial-leukocyte adhesion molecule-1 (ELAM-1) and vascular cell adhesion molecule-1 (VCAM-1). J. Clin. Invest. 89:1445-1452.

58. Dinther-Janssen, A. C. H. M., E. Horst, G. Koopman, W. Newmann, R. J. Scheper, C. L. J. M. Meijer, and S. T. Pals. 1991. The VLA-4/VCAM-1 pathway is involved in lymphocyte adhesion to endothelium in rheumatoid arthritis. $J$. Immunol. 147:4207-4210.

59. Marlor, C. W., D. L. Webb, M. P. Bombara, J. M. Greve, and M.-L. Blue 1992. Expression of vascular cell adhesion molecule-1 in fibroblastlike synoviocytes after stimulation with tumor necrosis factor. Am. J. Pathol. 140:1055-1060.

60. Grober, J. S., B. L. Bowen, H. Ebling, B. Athey, C. B. Thompson, D. A. Fox, and L. M. Stoolman. 1993. Monocyte-endothelial adhesion in chronic rheumatoid arthritis. J. Clin. Invest. 91:2609-2619.

61. Kocher, O., S. P., Kennedy, and J. A. Madri. 1990. Alternative splicing of endothelial cell fibronectin mRNA in the IIICS region. Am. J. Pathol. 137:15091524.

62. Wang, A., D. S. Cohen, E. Palmer, and D. Sheppard. 1991. Polarized regulation of fibronectin secretion and alternative splicing by transforming growth factor $\beta$. J. Biol. Chem. 266:15598-15601. 